Spring 2017

\title{
Where Are All the Black Teachers? Discrimination in the Teacher Labor Market
}

\author{
Diane D'Amico \\ Robert Pawlewicz \\ University of North Dakota, robert.pawlewicz@UND.edu \\ Penelope M. Earley \\ Adam P. McGeehan
}

How does access to this work benefit you? Let us know!

Follow this and additional works at: https://commons.und.edu/acc-fac

Part of the Education Commons

\section{Recommended Citation \\ Diane D'Amico, Robert Pawlewicz, Penelope M. Earley, et al.. "Where Are All the Black Teachers? Discrimination in the Teacher Labor Market" (2017). Accountancy Faculty Publications. 3. https://commons.und.edu/acc-fac/3}

This Article is brought to you for free and open access by the Department of Accountancy at UND Scholarly Commons. It has been accepted for inclusion in Accountancy Faculty Publications by an authorized administrator of UND Scholarly Commons. For more information, please contact und.commons@library.und.edu. 
PRE-PRINT VERSION

The following is the authors' final draft of a manuscript that was accepted for publication and, after editing and typesetting, was published as:

Where Are All the Black Teachers? Discrimination in the Teacher Labor Market By DIANA D'AMICO, ROBERT J. PAWLEWICZ, PENELOPE M. EARLEY, AND ADAM P. MCGEEHAN

Harvard Educational Review 87:1 (Spring 2017) pp. 26-49

https://hepgjournals.org/doi/10.17763/1943-5045-87.1.26

This PRE-PRINT copy is intended for non-commercial research and educational use only, including for instruction at the author's institution and sharing with colleagues, as well as for archiving purposes. All other uses, such as reproduction and distribution, or selling or licensing copies, or posting to third party websites, are prohibited unless authorized by separate license.

For further information, or for permission to reprint or to purchase copies of the final published version of the article, please contact Harvard Education Publishing Group (HEPG) at hepg@ @arvard.edu, or 617-495-3432.

The Harvard Educational Review (ISSN 0017-8055) is a scholarly journal of opinion and research in education. Its mission is to provide an interdisciplinary forum for discussion and debate about education's most vital issues. Since its founding in 1930, the Review has become a widely recognized journal in education, with circulation to policymakers, researchers, administrators, and teachers. The Review is published by Harvard Education Publishing Group.

Contact HEPG at:

8 Story Street, 1st Floor

Cambridge, MA 02138

617-495-3432 ph

617-496-3584 fax

hepg@ harvard.edu

https://hepgjournals.org/

Thank you. 


\section{Where are All the Black Teachers?: Discrimination in the Teacher Labor Market}

Diana D’Amico, Robert J. Pawlewicz, Penelope M. Earley, and Adam P. McGeehan

Of the nearly 4 million elementary, middle, and high school teachers in the United States, $83 \%$ are White and only $8 \%$ are Black ("Census 2000 EEO Data Tool," n.d.), even as more than $15 \%$ of the nation's school-age children are Black (United States Census Bureau, 2010). Echoing the concerns of policymakers and researchers, Secretary of Education Arne Duncan described the lack of racial diversity in the teaching profession as "especially troubling" (Duncan, 2010). For many, the central problem rests on the skewed demographic proportions of the profession. According to the National Education Association (n.d.), "Every child has a basic right to a great public school with a qualified and caring staff, including educators who look like them."

For the past several decades, policymakers and researchers have defined the paucity of Black teachers as a supply problem that impacts Black children most directly. In this article, we examine the racial composition of one teacher labor market through teacher applicant data and subsequent hiring decisions. We find evidence that even as qualified Black applicants applied to teach in the district, their chances of receiving an offer were significantly lower than White candidates, indicating discrimination in the teacher labor market. Ceteris paribus, Blackness was negatively associated with receiving a job offer in this school district; when Black candidates were hired they were disproportionately placed either in schools with large populations of children of color or children in poverty, or they were offered positions by Black principals. Possible explanations for this could be that the Black applicants were either unqualified or expressed a specific preference to teach in certain schools. Contrary to such suppositions, our results show that Black and White candidates were similarly qualified. Further, due to district hiring practices, candidates do not apply to specific schools but instead to the district for general 
2 | Where are All the Black Teachers?

position types. We maintain that this labor market discrimination - a manifestation of the low demand for Black teachers - matters not just for Black children who lack same-race role models but for all children.

Researchers concur that the racial composition of the teacher workforce is impacted by supply-side economic factors (Madkins, 2011), and they have examined these from a variety of important perspectives. For instance, some scholars have identified critical barriers to entry ranging from certification exams to negative portrayals of Black teachers that deplete the supply of racially diverse candidates (Albers, 2002; Foster, 1991; Milner, 2012; Petchauer, 2012; Santelices \& Wilson, 2010; Torres, Santos, Peck, \& Cortes, 2004). Examining the same supply dynamics from a different perspective, other researchers have highlighted the forces that pull racially diverse candidates away from the schools (Bianco, Leech, \& Mitchell, 2011; Franklin, 1987). Moving beyond individual motivations, scholars have also examined the institutional patterns that negatively impact the supply of racially diverse prospective teachers and called important attention to the prohibitive nature of standardized tests and the extent to which they constrict the racial diversity of the teacher labor market (Albers, 2002; Angrist \& Guryan, 2008; Petchauer, 2012). Likewise, scholars have looked to schools of education and the racialized undertones of preparation programs (Dixson \& Dingus, 2007; Ladson-Billings, 2000). Arguing that the nature of many preparation programs curtails the supply of racially diverse applicants, scholars have called for the restructuring of college education programs to become more culturally relevant to minority students and more proactive in preparing future educators for teaching African American students (Bridges, 2011; Ladson-Billings, 2000; Pabon, Anderson, \& Kharem, 2011; Petchauer, 2012; Sleeter, 2001). Extending this work, researchers have also examined alternate routes, questioning the extent to which they ease access into the profession or 
3 | Where are All the Black Teachers?

serve as a barrier for prospective teachers of color (Haberman, 1999; Lau, Dandy, \& Hoffman, 2007; Pabon, et al., 2011).

Given the evidence that African American students stand to benefit from encountering teachers of the same race in the classroom (Madkins, 2011; Villegas \& Irvine, 2010), programs have emerged across the nation that focus on targeted recruitment initiatives and alternate pathways into the profession (Boyd, et al., 2011; Haberman, 1999; Kirby \& Hudson, 1993; Lau, et al., 2007). Researchers have also observed that the supply issues transcend the point of initial entry and highlighted the need for retention initiatives (Ingersoll \& May, 2011). Even as the number of Black teachers has increased over the past decades (Ingersoll, Merrill, \& Stuckey, 2014), they have risen in proportion with the rest of the teaching profession and skewed demographic patterns persist, suggesting that these strategies have been less than effective (Achinstein, Ogawa, \& Speiglman, 2004; Madkins, 2011; Talbert-Johnson, 2001; Torres et al., 2004).

In large measure, the intractable nature of this phenomenon is historic and stems from the very ways in which the core problem has been defined (Colleague \& Author, 2015). In the popular imagination and textbooks alike, the Brown v. Board of Education decision of 1954 represents a critical turning point in the nation's history, a clear dividing line demarcating a racist past from an equitable present. However, the Brown case also represents something much less romantic: the displacement of the nation's African American teachers (Fairclough, 2004; Fultz, 2004; Hudson \& Holmes, 1994; Milner \& Howard, 2004; Tillman, 2004). Before the ruling, segregation was the law of the land. The systematic exclusion of Black children and families from public schools, particularly in the South but elsewhere, too, was indicative of the racist ideals that structured the nation's economic, political, and social landscape. In the face of 
4 | Where are All the Black Teachers?

segregation, Black families resisted and persisted in overt and subtle ways. As historian James Anderson (1988) has detailed, Black families in the South pooled economic and less tangible resources like time to build schoolhouses, discuss curricular matters, and hire teachers. These children learned in vastly unequal settings but, as Vanessa Siddle-Walker (2000) has argued, the presence of Black teachers also gave deep value to their education. With the Brown decision, these community-supported schools and the Black teachers who staffed them were wiped away as courts mandated the integration of the nation's school children but said nothing of the teacher labor force, effectively diminishing the demand for Black teachers.

Conditions, such as the lack of racial diversity among the nation's teachers, exist and are tangible. The act of defining those conditions as problems, on the other hand, is a social and political byproduct (Baumgartner \& Jones, 2009; Kingdon, 1984; Rochefort \& Cobb, 1994). The very ways researchers and policymakers define the educational problems of the day determine the lens through which we understand and attempt to solve them. Turning a blind eye to the historic forces surrounding the employment of Black teachers and the ways pre-Brown ideals continue to shape the post-Brown world, most policymakers have defined endemic diversity problems as a function of supply rather than demand.

The role of race in teacher hiring practices has received only slight consideration from researchers and policymakers. Many hiring practices are what Liu \& Johnson (2006) call moderately decentralized. Teachers are technically hired and employed by the district, but the actual selection is made by principals at individual schools (Engel \& Cannata, 2015). Black teachers constitute a smaller percentage of the teaching workforce and are more likely to teach minority students in urban schools (Hanushek \& Rivkin, 2007; Jacob, 2007; Mertz, 2010). Is this a function of supply or demand, though? In most districts around the nation, principals are the 
5 | Where are All the Black Teachers?

gatekeepers of the schools, granting or denying entry via job offers. An examination of the results of the decisions they make is essential to understanding which market forces are at play. When faced with a hiring decision, principals often consider a multitude of factors related to teacher qualities and the context of their schools (Ingle, Rutledge, \& Bishop, 2011). And as other researchers have documented, some principals prioritize other candidate characteristics like local connections or experience (Authors, 2015; Boyd, Lankford, Loeb, \& Wyckoff, 2013). Some administrators report placing no considerable value on the ethnicity or race of candidates (CainCaston, 1999) or if they can teach students of different races (Dillon, McCaughtry, \& Hummel, 2010), whereas others prioritize race (Harris, Rutledge, Ingle, \& Thompson, 2010). Meanwhile, studies of other fields have revealed discriminatory practices in hiring and, in particular, a reluctance to hire Black applicants (Bertrand \& Mullainathan, 2004); to what extent, if any, might similar tendencies manifest in the education labor market? The teacher labor market is geographically small and highly localized (Engel \& Cannata, 2015). As a result, principals develop definitions of fit regarding which candidates are best suited for their individual schools (Hanushek \& Rivkin, 2007; Ingle et al., 2011; Mertz, 2010). Districts in some studies have implemented policies to recruit and hire minority teachers (Ingle et al., 2011; Jacob, 2007; Madkins, 2011), but what impact do these district policies have on the hiring decisions of individual principals?

In this article we examine the demographic composition of the teacher labor market from a new perspective. With few exceptions (Author, 2015; Dobbie, 2011; Goldhaber, et al., 2014), researchers have focused their analyses on ex-post data of teachers already hired and working in the system and, as a result, have yet to examine applicant pool data. This study questions the extent to which supply issues alone account for the paucity of Black teachers through an 
6| Where are All the Black Teachers?

examination of teacher applicant data and hiring decisions in a single school district. In spring 2012, 11,980 applicants submitted 27,330 applications for 2,380 open teaching positions. Each year, the district allocates resources to the recruitment of minority candidates in an explicit effort to increase the diversity of its teaching population, identifying supply as the root cause of its homogenous teacher corps. Those efforts bore fruit in the applicant pool where Black candidates comprised $13 \%$ of prospective teachers, a proportion slightly greater than the percentage of Black students in the district (10\%). However, Black teachers represented only $6 \%$ of those offered positions in the district.

To be sure, racial diversity is an issue that transcends the Black community. As our data reveal, the percentage of job offers extended to Black, Hispanic, and Asian teachers fell far below the percentage of Black, Hispanic, and Asian students in the district. That said, Hispanic and Asian teachers were hired in similar proportions to which they applied, suggesting that the low numbers for these groups may indeed reflect a supply problem. The patterns surrounding Black teachers, however, were starkly different: the offer rate for these teachers was disproportionately less than the rate at which they applied, suggesting other contributing forces exist.

Discrimination is a powerful word and one that is often avoided because of what it connotes. However, the economic definition of the term is simple and clear: "Discrimination is generally understood to exist when some superficial characteristic (skin pigmentation, for example) is used in an attempt to restrict individuals' access to the available economic, political, and social opportunities for advancement" (D’Amico, 1987, p. 310). In this district, Black applicants, though similar in many attributes to their White counterparts, encountered a significantly lower likelihood of being offered a job, replicating discriminatory employment 
7 | Where are All the Black Teachers?

patterns documented across a range of industries (Bertrand \& Mullainathan, 2004). Further, White principals hired disproportionately fewer Black teachers than Black principals did.

Finally, we find evidence of workforce segregation. When Black teachers were hired, they were disproportionately placed in schools with large populations of minority students or students living in poverty. This research does not negate the important work on the real and pervasive supply-side problems when it comes to the racial composition of the teacher corps. However, our findings also suggest that even increasing the supply of racially diverse teachers, as this school district has, may not be enough to diversify the nation's corps of public school teachers. Another powerful and historic force is also at work: demand. In this district, the supply of qualified Black teachers outpaced the demand for them.

\section{Background and Context}

\section{Overview of the School District}

The school district studied in this research ranks among the largest school districts in the nation and serves more than 180,000 students (U.S. Department of Education, 2010). Near a major metropolitan area, the largely suburban district maintains over 180 schools and is sustained by an operating budget in excess of $\$ 2$ billion; the average per pupil expenditure is $\$ 13,000$. With a funding structure much like that of districts around the nation, the majority of financial resources come from the locality, $15 \%$ of the budget comes from the state, and less that $2 \%$ comes from federal aid. Teachers represent the largest budget expenditure, and there are over 20,000 full-time positions in the district. Approximately $40 \%$ of the student population in the district is White. African American students comprise approximately $10 \%$ of the student population; Hispanic and Asian students each represent $20 \%$ of the district's student population. 
8 | Where are All the Black Teachers?

Over one-quarter of the students who attend school in the district qualify for free and reduced lunch programs; approximately $15 \%$ of students garner the ESOL classification, and approximately $15 \%$ of students receive special education services. Based on standardized assessments, the district is widely praised as "high performing."1

\section{District-Level Hiring Practices and Policies}

Each year, representatives from the centralized Human Resources (HR) Department travel within and beyond state limits to diversity fairs, Historically Black Colleges and Universities, and recruitment events with the goal of attracting racially diverse candidates to the district. In addition, the HR Department hosts on-line recruitment events in an endeavor to reach desirable and geographically diverse candidates. To begin the application process, all prospective applicants must submit licensure and certification credentials via an online system. Staff members in the district's HR Department perform an initial screen to ensure that candidates meet basic state requirements. If they do, the candidate is sent a link to complete the online application and a code to take the TeacherInsight (TI) assessment administered by Gallup.

All candidates must submit their applications via a single, centralized, online system where they upload resumes, cover letters, and enter information pertaining to current residence, educational background, and work experience. ${ }^{2}$ In addition, candidates have the opportunity to submit identifying demographic information pertaining to the Equal Employment Opportunity Commission (EEOC); the EEOC information is not shared with hiring principals. Principals first gain definitive information about a candidate's race during the in-person interview. However, researchers have found that individuals screening applications also derive information or make

\footnotetext{
${ }^{1}$ All information is publically available on the district's website, but identifying information is withheld to maintain anonymity at the request of the district.

${ }^{2}$ This research is based on application information entered into the online system. The district did not provide the uploaded documents to preserve the anonymity of candidates.
} 
9 | Where are All the Black Teachers?

assumptions about racial backgrounds from candidate names and other information included in the resume (Bertrand \& Mullainathan, 2004). Regardless of when or how a principal learns of the candidate's race, racial background is known before an offer is extended.

Candidates may be aware of openings at particular schools either through personal connections or school webpages, but when submitting materials they do not have an opportunity to specify a school preference. Instead, prospective teachers apply to general position types (i.e., middle school mathematics). After online applications are complete, HR staff members send hiring principals links to relevant applications. Once principals have identified applicants of interest, they personally contact the individual to arrange an interview. Principals do not notify the centralized HR Office about individuals interviewed and as such, no data exists regarding how many or which candidates are interviewed. However, district officials recounted anecdotal information from principals that invitations to interview were rarely declined, replicating patterns documented elsewhere (Goldhaber et al., 2014). Principals notify HR staff of the candidates they wish to hire and HR staff contact successful candidates to extend offers. As a way to ensure that all schools in the district have an opportunity to hire the "best" applicants, district policy gives principals of "priority schools" - schools that receive Title I funding or schools that are not meeting performance benchmarks - the ability to extend offers before the rest of the schools in the district. Scholars have called attention to the role of teacher preferences in school placements (Boyd, et al., 2005; Reininger, 2012). Unlike other districts, candidates in this district may not exert preference by applying only to particular schools. Instead, prospective teachers in this context exercise their preferences at three junctures: 1) when they choose to apply to the district, 2) when they accept or decline an invitation to interview, 3) when they accept or decline a job offer. 


\section{Data, Methods, and Statistical Model}

This study is based on the population of completed applications for teaching positions in the district for AY 2012-2013, including EEOC data. We obtain information regarding position opening (subject and school level); whether the TI score threshold was met; applicant ZIP code; prior school experience (location and amount); and education (level, subject, location, and school type). In addition to application information, we derive student population and principal data for schools in the district that hired for the 2012-2013 school year including priority school designation and demographic information regarding race, ethnicity, and free and reduced lunch participation published on the district's website. Finally, we have data on hiring decisions and the dates that the offers were extended.

The goal of this research is to examine the role of race in the hiring process for teachers. Prior research has documented that both the qualifications of the candidate and the candidate's ties to the local area play an important role in teacher hiring decisions. Using all of the information contained in the online applications provided by the district, we construct a number of proxies to control for the qualifications and local ties of the candidates in our regression analyses to isolate the role of race in hiring decisions. ${ }^{3}$ Proxies include whether or not candidates surpassed the suggested TI assessment score, ${ }^{4}$ the type of higher education institution attended, and highest degree earned, among others. As prior research has shown that candidates' local ties may make them more attractive candidates, we create a number of variables that proxy for localism (Author et al. 2015; Boyd et al. 2013), such as prior work experience within the district, receiving a degree from a post-secondary institution located in the district, and whether the

\footnotetext{
${ }^{3}$ Please refer to Table 2, Panel B for the full list of variable definitions.

${ }^{4}$ We include a variable for passing the suggested TI score because the HR Office does not provide principals in the district (or the authors) with the raw candidate score.
} 


\section{1 | Where are All the Black Teachers?}

candidate lives in the district, among others. In addition to the variables we create from online applications, we utilize publicly available school demographic information to examine the types of schools that hire Black teachers and create five variables that characterize various school types in the district. ${ }^{5}$ Finally, we use information from the district's website to identify the race of each principal that made job offers using the same EEOC categories as applicants.

To estimate the likelihood of receiving a job offer in the district, we use binary logistic regression of the following form:

$$
P\left(Y_{i}=1\right)=\frac{\exp \left(\beta \mathrm{X}_{i}\right)}{1+\exp \left(\beta \mathrm{X}_{i}\right)}
$$

In the model, $Y_{i}$ is a dichotomous variable that takes the value of 1 if the application $i$ received a job offer, and 0 otherwise. The independent variables of interest in our model are the applications with races identified as non-White or left blank. ${ }^{6}$ We also included proxies for the applicants' qualifications and local ties as control variables. All independent variables are included in the vector $\mathrm{X}_{i}$, and $\beta$ is the vector of parameters associated with $\mathrm{X}_{i}$. We base our statistical inferences on standard errors clustered by candidate as each individual may apply for multiple job postings.

\section{Results}

\section{Racial Composition of Applications and Offers}

As reported in Table 1, Panel A, whereas $40 \%$ of the district's students are White, $70 \%$ of all applications were submitted by White candidates and over $77 \%$ of job offers were given to

\footnotetext{
${ }^{5}$ Please refer to Table 4 for a full list of variable definitions related to school and principal demographic information.

${ }^{6}$ Note that we did not include a variable for applications from White candidates so the marginal effect of Whiteness is captured in the regression model intercept and is the comparison point for all other racial variables.
} 


\section{2 | Where are All the Black Teachers?}

White candidates. Conversely, $20 \%$ of the student population was Hispanic but less than $5 \%$ of offers were given to Hispanic candidates, who comprised a similar proportion of the application pool. Further, Black students comprised $10 \%$ of the student population and just less than $13 \%$ of the teacher application pool, but Black candidates received only $6 \%$ of job offers. Even as Black candidates comprised a similar percentage of the application pool as the student population, disproportionately fewer offers were given to Black candidates. Principals awarded White candidates seven percentage points more in offers than their proportion in the application pool, whereas principals offered Black applicants positions seven percentage points less than their proportion in the application pool. These statistics provide preliminary evidence that Black candidates were hired disproportionately less than their White counterparts.

Table 1, Panel B provides initial statistical evidence of the association between race and the likelihood of being offered a job in the district. Identifying as Black was negatively correlated $(\rho=-0.06)$ with receiving a job offer whereas identifying as White was positively correlated $(\rho=0.05)$ with receiving a job offer. ${ }^{7}$ None of the other EEOC racial categorizations exhibits a significant correlation with the likelihood of receiving a job offer. ${ }^{8}$ Before taking other factors into consideration, identifying as Black (White) was negatively (positively) correlated with candidates' likelihood of receiving a job offer.

Are Black Applicants as Qualified as White Applicants? As researchers concur that teachers stand among the most critical determinants of student success (Heck, 2007), one might assume that hiring principals make economically rational decisions and hire the most qualified applicants. Following this logic, one possible explanation for the discrepancy in job offer rates

\footnotetext{
${ }^{7}$ Both correlations are significant at the $1 \%$ level.

${ }^{8}$ The district allows applicants the option to self-identify as White, Black, Hispanic, Asian, American Indian, Alaska Native, Native Hawaiian or Pacific Islander. We aggregate the remaining groups into a catch-all 'Other' category because of their small numbers. The district created a category labeled 'Multiple' for applications marking more than one race.
} 


\section{3 | Where are All the Black Teachers?}

between White and Black candidates could be that Black candidates are less qualified than White candidates. We investigate this potential explanation by comparing the application characteristics of Black and White candidates in Table 2, Panel A. The results in this panel provide evidence that Black candidates differed from their White counterparts, but not in ways that would indicate lower quality. On average, Black candidates had more advanced degrees (i.e., 23 percentage points more likely to have a graduate degree), were more likely to have a degree from a university in the closest metropolitan area or from an institution on the district's list of standard universities, had more out-of-district school experience (i.e., almost two years of additional experience), but were more likely to live outside of the district than White candidates. Black candidates were also significantly less likely to pass the suggested TeacherInsight score (i.e., 58\% passing rate for Black candidates and $65 \%$ passing rate for White) or have a degree from the university located within the district.

In Table 2, Panel B, we compare the application characteristics of Black and White candidates who received offers to identify differences in teachers receiving jobs in the district. Black and White candidates who received job offers from the district are more similar than different with a few notable exceptions. Successful Black candidates held significantly more advanced degrees, had more experience outside the district, but were less likely to live in the district than successful White candidates, echoing differences between Black and White applicants. While Black applicants were slightly less likely than White applicants to have district experience (i.e., 17\% of Black applicants and 18\% of White candidates listed district experience), Black candidates receiving offers were significantly more likely to have district experience (i.e., $57 \%$ of Black and $49 \%$ of White candidates hired listed district experience). 


\section{4 | Where are All the Black Teachers?}

Again, differences in application characteristics generally do not indicate substantial lower quality for Black candidates compared to White candidates.

Author et al. (2015) document evidence that the characteristic most predictive of receiving a job offer in this district was prior in-district work experience. To investigate whether our findings of hiring discrimination could be explained by a lack of in-district experience for Black candidates, we execute additional tests. We disaggregate our sample of applications into those that claimed in-district work experience and those that did not, and divide those subsamples by race to examine job offer rates in Table 1 , Panel C. We find that $26 \%$ of applications from White candidates who listed in-district experience were offered jobs but only $14 \%$ of applications from Black candidates who also listed in-district experience were offered jobs, and this difference $(12 \%)$ is statistically significant at the $1 \%$ level. These results indicate that Black candidates received proportionately fewer job offers than their White counterparts, even after considering prior work experience in the district.

Finally, we use logistic regression to hold all of the application characteristics constant while determining the marginal effect of each characteristic on the likelihood of the application receiving a job offer. Table 3 presents the parameter estimates, point estimates and 95\% confidence-level bounds of the odds ratios for the variables of interest from the logistic regression. ${ }^{9}$ These results indicate that the race of the applicant is significantly associated with the likelihood of receiving a job offer. Ceteris paribus, an application from a Black candidate was $52 \%$ less likely $(\hat{\beta}=-0.74$; Odds Ratio point estimate of $48.1 \% ; p<0.001)$ to receive an

\footnotetext{
${ }^{9}$ We leave the information associated with the control variables untabulated to conserve space but parameter estimates for all control variables are similar in sign and significance to Author et al. (2015).
} 


\section{5 | Where are All the Black Teachers?}

offer than one from a White candidate. ${ }^{10}$ Said another way, a Black applicant would be half as likely to receive a job offer as a White candidate with identical qualifications.

Are Black Applicants Applying Where the Jobs Are? Another possible explanation for the discrepancy in job offer rates between White and Black candidates could be that Black candidates are not applying to positions with the most jobs (Lilien, 1982). We investigate this possibility by comparing the application and offer rates of Black and White candidates at different school levels (elementary, middle, high, and other types of schools) and across different positions.

In the district, $55 \%$ of job offers are made in elementary schools, while $13 \%$ are made at middle schools, $20 \%$ are made at high schools, and $12 \%$ are made at other types of schools. In untabulated analyses, we find evidence that Black and White candidates apply in statistically similar proportions for positions in middle schools and high schools. Proportionally fewer (more) Black candidates applied for positions at the elementary level (other levels) than White candidates. Despite these differences in application rates, Black candidates were offered positions at significantly $(p<0.01)$ lower rates than White candidates for all school levels. Additionally, we execute the regressions from Table 3 separately by the four school-level types and find that candidates identified as Black experienced a significantly lower likelihood of being offered a job offer at all school types.

We also examine whether Black candidates did not apply for high-demand positions in areas such as STEM and special education. The district hired 206 STEM teachers and 466

\footnotetext{
${ }^{10}$ In untabulated analyses, we perform the regression analysis using only the Black independent variable, then include the other race variables without the remaining control variables. The coefficient estimate for the Black variable is negatively significant at the $0.1 \%$ level in both and the odds ratio point estimate is $-57.5 \%$ in the uncontrolled regression and $-58.9 \%$ in the regression with the other race variables. We caution against drawing conclusions from uncontrolled regressions because their model fit is not high (the area under the ROC curve is less than 55\% for both) and principals likely do not base hiring decisions solely on the applicant's race.
} 


\section{6 | Where are All the Black Teachers?}

special education teachers in the year of study. Black candidates submitted 235 applications for STEM teaching positions (6.9\% of total Black applications) but only 11 were hired in the district (a success rate of 4.6\%). Similarly, Black candidates submitted 716 applications for special education positions (21\% of total Black applications) but received only 39 job offers for these positions (a success rate of 5.4\%). White candidates enjoyed success rates greater than Black candidates for both STEM (11.8\% for White candidates) and special education $(11.3 \%$ for White candidates) positions. Finally, we execute the regressions from Table 3 separately for both STEM and special education positions and find that candidates identified as Black experienced a significantly lower likelihood $(p<0.01)$ of being offered either type of position. Given the lower success rate for Black candidates, it is unclear that increasing the supply of Black applications would increase the hiring of Black teachers in the district.

\section{Racial Characteristics of Hiring Principals and School Demographics}

Next we investigate whether certain schools and principals were more likely to extend job offers to Black candidates than others. In Table 4, we present evidence that offers made to Black candidates disproportionately came from certain schools. The district's 24 Black principals (13\% of principals) extended $12 \%$ of their offers to Black candidates, while schools with large populations of Black students and students living in poverty devoted $11 \%$ and $10 \%$ of their offers, respectively, to Black candidates. Meanwhile, Black candidates were significantly less likely to receive job offers from the district's 157 White principals ( $83 \%$ of principals) or schools with large White student populations, which made $4 \%$ and $3 \%$ of their job offers to Black candidates. 


\section{7 | Where are All the Black Teachers?}

Schools with large populations of Black students hired 632 teachers during our study, of those 70 were Black (slightly less than half of all Black teachers hired across the entire district). In contrast, schools with very large White student populations hired 480 new teachers (only 14 Black). The district's 157 White principals hired 1,221 new teachers (only 49 Black) while the district's 24 Black principals hired 23 Black teachers. Researchers agree that same-race role models are particularly valuable for Black students (Dee, 2004), perhaps leading some to wonder if the placement of Black teachers in this district only echoes scholars' calls. However, even in schools with large populations of Black students, Black candidates were hired at a rate substantially lower than that of White candidates. In no school context in this district were Black teachers hired in equal proportions to White teachers. Further, the near absence of Black teachers in the district's other schools, particularly in schools with large populations of White students, provides evidence of labor market segregation, another discriminatory hiring practice.

Does the Timing of the Offer Impact the Placement of Black Teachers? Per district policy, principals at priority schools have the ability to extend job offers before others. One possible explanation for the segregation of the district's new Black teachers could revolve around timing (Engel, 2012): do priority schools hire Black teachers before other schools, thus consuming the entire supply of Black teachers? To investigate this possibility we examine the timing of job offers made by principals at priority schools to both Black and White candidates in Figure 1 (Panel A and B). Despite the sizable differences in the numbers of White and Black teachers hired, most offers were made during the summer months (June, July and August), as shown in Panel A. Panel B depicts the timing of the proportion of job offers in the district and, again, most offers were made during the summer. ${ }^{11}$ If the Black teachers hired were offered

\footnotetext{
${ }^{11}$ Priority schools hired 388 teachers, only 35 were Black, which does not represent the entire population of Black candidates.
} 


\section{8 | Where are All the Black Teachers?}

positions earlier than their White counterparts, thus depleting the supply of Black candidates, one would expect to see the solid black line shifted to the left in the graph with a peak during the earlier months followed by a subsequent dip. Instead, the graph displays that the timing for hires was similar for candidates regardless of race. ${ }^{12} \mathrm{We}$ find no evidence to support the alternate explanation regarding the timing of offers to Black candidates. Furthermore, this explanation overlooks the fact that large numbers of qualified Black candidates remained in the applicant pool but were not hired.

Are Black Teachers Declining Offers? Another alternate explanation for our findings that Black teachers hired were segregated into certain schools could stem from teacher preferences (Horng, 2009): perhaps Black candidates turned down offers from schools with White principals and schools with large populations of White students? The data provided by the district does not identify job offers declined by candidates. However, representatives from the central HR Office confirmed that instances of declined offers were rare, pointing to the district's reputation as a desirable place to work. Furthermore, district officials affirmed that in the few instances of declined offers, candidate race and the racial composition of the hiring school did not play an apparent role.

Limitations and Directions for Future Research We acknowledge that the nature of this research creates limitations for generalizability of the results. As we only obtained data from a single district for a single year, the results that we present may not be generalizable to other districts in other years. Further, the tests performed provide associations, do not identify causality, and may be subject to correlated-omitted variable bias. That said, all of the results presented have been supported by multiple tests with robust controls whenever possible. In the

\footnotetext{
${ }^{12}$ In untabulated analyses, we also prepared the same graphs for all offers awarded and offers made by non-Priority schools. These graphs follow a similar pattern as the Priority schools.
} 


\section{9 | Where are All the Black Teachers?}

future, researchers may perform similar analyses in other districts to expand the findings from this study. Future researchers may also attempt to conduct surveys or interviews with hiring principals in order to determine the driving forces behind hiring decisions.

\section{Discussion}

The lack of racial diversity in the teaching profession has captured the attention of researchers and policymakers for the past several decades. Agreeing that minority children stand to benefit from same-race role models, the problem has been defined with a blind eye to history as a function of supply-side dynamics: either because of better options elsewhere or barriers to entry, not enough Black adults come to the nation's schools. As a result, treatments have centered squarely on recruitment in the form of greater outreach, alternate pathways into the profession, and retention endeavors. Despite decades of reform, the demographic composition of the teaching population has remained static and skewed, even as raw numbers have increased (National Collaborative on Diversity in the Teaching Force, 2004). In this research, we question the fundamental assumption of supply issues by examining teacher applications and subsequent hiring decisions in a single school district.

In the district studied, local policymakers expressed concern over the lack of racial diversity among teachers and identified recruitment as a salve. Our analysis finds that their efforts were partly successful. Black candidates submitted $13 \%$ of applications, a proportion greater than the percent of Black students in the district. Racially diverse candidates applied to teach in the district, but their chances of getting hired were low, and only $6 \%$ of Black candidates were offered positions. Ceteris paribus, identifying as Black was negatively associated with receiving a job offer in the district. That said, some Black candidates were offered positions in 


\section{0 | Where are All the Black Teachers?}

the district and those candidates were more likely to be hired by Black principals than White principals. Black teachers were also more likely to be hired in schools with large populations of minority children or children in poverty.

The implications of these findings are important and far-reaching. First, there is no simple pathway to racial diversity. Questions of supply that focus on recruitment initiatives and potential barriers to entry are important and, as our research suggests, may be particularly germane to increasing the Asian and Hispanic teaching population in the district. But, as our findings also suggest, supply alone cannot explain the demographic composition of the teacher labor market. Diversification of the workforce, particularly the professions, has received broad attention and solutions have centered largely on increasing supply. What if racially diverse people are, indeed, applying for these positions but are not getting hired? The persistent focus on supply is the byproduct of a lack of historical engagement. From an institutional and structural perspective, the nation's public schools have proved highly durable (Tyack \& Cuban, 1997; Tyack \& Tobin, 1994). Even as the historic Brown decision stands as a watershed moment, racialized assumptions and ideologies continue to inform the institutional logic of public schooling in both form and function (Author, 2016). To what extent might contemporary hiring practices and the very demographic composition of the teacher corps be an outgrowth of this legacy?

Second, advocates for increased teacher diversity often point to the needs of racially diverse children to legitimate their claims. The fundamental logic motivating these calls centers on the idea that racially diverse teachers are important for similarly racially diverse students, a claim well-supported by scholarly literature. But what is at stake in limiting the importance of diverse teachers, broadly conceived, to demographically similar children? Is there no value of 


\section{1 | Where are All the Black Teachers?}

racial diversity to White children, for instance? When Black teachers were hired in the district studied, they were separated into to schools with children of color or children in poverty, albeit in numbers far lower than White candidates hired in these schools. The presence of Black teachers in these schools is important and should continue to increase, but their near absence from schools with large populations of White students ought to be questioned. More than six decades removed from the Brown decision and the Civil Rights Movement, racial antagonisms continue to erupt across the nation. What role might the lack of racially diverse exemplars for all of the nation's children play in these tensions? 
22 | Where are All the Black Teachers?

Table 1

Ethnicity Composition of Applications and Offers

\begin{tabular}{lcc}
\hline Panel A. Ethnicity of Applications & \\
\hline Ethnicity & $\frac{\% \text { of }}{\text { Applications }}$ & $\underline{\underline{\text { Offers }}}$ \\
White & $\frac{\underline{77.5 \%}}{70.2 \%}$ & $77.5 \%$ \\
Black & $12.5 \%$ & $6.0 \%$ \\
Hispanic & $4.5 \%$ & $4.8 \%$ \\
Other & $4.8 \%$ & $4.4 \%$ \\
Multiple & $3.2 \%$ & $3.1 \%$ \\
Blank & $4.6 \%$ & $3.7 \%$ \\
Number & 27,330 & 2,379 \\
\hline
\end{tabular}

Other includes Asian, American Indian, Alaska Native, Native Hawaiian and Pacific Islander. Multiple is a category created by the district for applications that marked more than one ethnicity.

\begin{tabular}{|c|c|c|c|c|c|c|}
\hline nel & of & ga & $\mathrm{r}$ with & & & \\
\hline & Black & White & Hispanic & Other & Multiple & Blank \\
\hline Offered & -0.06 & 0.05 & 0.01 & -0.01 & 0.00 & -0.01 \\
\hline
\end{tabular}

Correlations in bold, italics indicate significance at the 0.01 level.

Offered is an indicator variable that equals one if the application received an offer for employment in the district, and zero otherwise.

Panel C. Offer Rates for Black and White Applications by District Experience

No District Experience

\begin{tabular}{|c|c|c|c|c|c|}
\hline Applications & White & $\underline{\text { Black }}$ & Difference & $\underline{T-S t a t}$ & Sig. \\
\hline Offer Rate & $6 \%$ & $2 \%$ & $-4 \%$ & -11.70 & $* * *$ \\
\hline Number & 15,781 & 2,840 & & & \\
\hline
\end{tabular}

District Experience

\begin{tabular}{|c|c|c|c|c|c|}
\hline Applications & White & Black & Difference & T-Stat & Sig. \\
\hline Offer Rate & $26 \%$ & $14 \%$ & $-12 \%$ & -6.94 & $* * *$ \\
\hline Number & 3,478 & 566 & & & \\
\hline
\end{tabular}

**** indicates significance at the 0.01 level. 
23 | Where are All the Black Teachers?

Table 2

Differences in Characteristics of Black Candidates

\begin{tabular}{|c|c|c|c|c|c|}
\hline \multicolumn{6}{|c|}{ Panel A. Differences in Application Characteristics } \\
\hline Variable & White & $\underline{\text { Black }}$ & Diff. & $\underline{\mathrm{T}-\mathrm{Stat}}$ & $\underline{\text { Sig. }}$ \\
\hline Offered & 0.10 & 0.04 & -0.05 & -13.38 & $* * *$ \\
\hline TICut & 0.65 & 0.58 & -0.07 & -8.44 & $* * *$ \\
\hline HighestDegree & 3.56 & 3.79 & 0.23 & 17.49 & $* * *$ \\
\hline Local_Ind & 0.11 & 0.09 & -0.02 & -3.91 & $* * *$ \\
\hline State_Ind & 0.29 & 0.30 & 0.01 & 2.19 & $* *$ \\
\hline Metro_Ind & 0.03 & 0.08 & 0.05 & 10.05 & $* * *$ \\
\hline Standard_Ind & 0.52 & 0.55 & 0.04 & 3.53 & $* * *$ \\
\hline Top50 & 0.09 & 0.04 & -0.04 & -10.95 & $* * *$ \\
\hline BachelorMatch & 0.48 & 0.32 & -0.16 & -17.92 & $* * *$ \\
\hline NonDistExp_Ind & 0.66 & 0.71 & 0.05 & 6.29 & $* * *$ \\
\hline NonDistExp_Years & 4.07 & 6.06 & 1.99 & 16.68 & $* * *$ \\
\hline DistExp_Ind & 0.18 & 0.17 & -0.01 & -2.01 & $* *$ \\
\hline DistExp_Years & 0.84 & 0.71 & -0.13 & -3.05 & $* * *$ \\
\hline LocalZIP_Ind & 0.26 & 0.20 & -0.06 & -6.76 & $* * *$ \\
\hline StateZIP_Ind & 0.09 & 0.14 & 0.05 & 8.00 & $* * *$ \\
\hline Observations & 19,192 & 3,406 & & & \\
\hline
\end{tabular}

\begin{tabular}{|c|c|c|c|c|c|}
\hline \multicolumn{6}{|c|}{ Panel B. Differences in Offer Characteristics } \\
\hline$\underline{\text { Variable }}$ & $\frac{\text { White }}{\text { Average }}$ & $\underline{\text { Black }}$ & $\underline{\text { Diff. }}$ & $\underline{\mathrm{T}-\mathrm{Stat}}$ & $\underline{\text { Sig. }}$ \\
\hline HighestDegree & 3.64 & 3.82 & 0.18 & 3.53 & $* * *$ \\
\hline NonDistExp_Years & 3.55 & 5.20 & 1.65 & 3.50 & $* * *$ \\
\hline DistExp_Ind & 0.49 & 0.57 & 0.08 & 1.97 & $* *$ \\
\hline LocalZIP_Ind & 0.48 & 0.38 & -0.10 & -2.16 & $* *$ \\
\hline RegionZIP_Ind & 0.21 & 0.29 & 0.08 & 2.35 & $* *$ \\
\hline StateZIP_Ind & 0.05 & 0.10 & 0.05 & 1.93 & $*$ \\
\hline Observations & 1,942 & 143 & & & \\
\hline
\end{tabular}

$* * *, * *$, and $*$ indicate significance at the $0.01,0.05$ and 0.10 levels, respectively.

To conserve space, we suppress variables for which Black and White candidates do not significantly different levels of the variables.

TICut is an indicator variable that equals one if the application included a TI score that met the minimum suggested TI score for the position. HighestDegree is an ordinal variable that relates to the highest degree that the candidate earned, where $1=$ High School Diploma / GED; $2=$ Associates Degree; 3 = Bachelor Degree; 4 = Master Degree; 5 = Doctorate. Local_Ind is an 
indicator variable that equals one if applicant the earned a degree from the nearest university. State_Ind is an indicator variable that equals one if the applicant earned a degree from four-year college or university located in the district's state. Metro_Ind is an indicator variable that equals one if the applicant earned a degree from four-year college or university located in the nearest metropolitan area. Standard_Ind is an indicator variable that equals one if the applicant earned a degree from four-year college or university included in the list of district's "Standard Name" institutions. Top50 is an indicator variable that equals one if the applicant earned a degree from four-year college or university ranked $50^{\text {th }}$ or higher in U.S. News and World Report Top Colleges and Universities for 2012. BachelorMatch is an indicator variable that equals one if the applicant earned a Bachelor degree in the same content area as the position applied for.

DistrictExp_Ind is an indicator variable that equals one if the applicant listed work experience in the district. DistrictExp_Years is the sum of the number of years that the applicant listed as work experience with the district. NonDistrictExp_Ind is an indicator variable that equals one if the applicant listed school work experience outside of the district. NonDistrictExp_Years is the sum of the number of years that the applicant listed as work experience in schools outside of the district. LocalZIP_Ind is an indicator variable that equals one if the applicant listed a home ZIP code in the district. RegionZIP_Ind is an indicator variable that equals one if the applicant listed a home ZIP code in the region near the district. StateZIP_Ind is an indicator variable that equals one if the applicant listed a home ZIP code in the state but outside of the proximal region or district.

Table 3

Logistic Regression with Race

\begin{tabular}{lcccccc}
\hline & & & & & \multicolumn{2}{c}{$95 \%$ Confidence } \\
Interval Odds Ratio \\
$\underline{\text { Parameter }}$ & $\hat{\beta}$ & $\underline{\text { Wald } \chi^{2}}$ & $\underline{\text { Sig. }}$ & $\underline{\text { Odds Ratio }}$ & $\underline{\text { Lower }}$ & $\underline{\text { Upper }}$ \\
Intercept & -3.98 & 652.19 & $<.0001$ & & & $-43 \%$ \\
Black & -0.74 & 17.38 & $<.0001$ & $-52 \%$ & $-60 \%$ & $-43 \%$ \\
Hispanic & 0.01 & 64.65 & $<.0001$ & $1 \%$ & $-20 \%$ & $29 \%$ \\
Other & -0.36 & 0.01 & 0.9079 & $-30 \%$ & $-46 \%$ & $-11 \%$ \\
Multiple & -0.40 & 10.89 & 0.001 & $-33 \%$ & $-49 \%$ & $-12 \%$ \\
Blank & -0.53 & 9.54 & 0.002 & $-41 \%$ & $-56 \%$ & $-21 \%$ \\
\hline
\end{tabular}

The dependent variable is the indicator variable Offered and the regression model was run on 27,271 application observations with an $8.71 \%$ offer rate. The model includes all control variables from Table 2 and for gender. The model produces an $R^{2}$ of $6.57 \%, 74.6 \%$ concordant observations and $75.1 \%$ area under ROC. 
25 | Where are All the Black Teachers?

Table 4

Comparison of Offer Rates to Black Candidates across School Types

\begin{tabular}{|c|c|c|c|c|c|}
\hline$\underline{\text { Offers }}$ & $\underline{\text { Variable }}$ & $\begin{array}{l}\% \text { to Black } \\
\text { Candidates } \\
\end{array}$ & Diff. & $\underline{T-S t a t}$ & $\underline{\text { Sig. }}$ \\
\hline 1,221 & White Principal & $4 \%$ & $-4 \%$ & -3.75 & $* * *$ \\
\hline 869 & Not White Principal & $9 \%$ & & & \\
\hline 194 & Black Principal & $12 \%$ & $7 \%$ & 2.86 & $* * *$ \\
\hline 1,896 & Not Black Principal & $5 \%$ & & & \\
\hline 388 & Priority Schools & $9 \%$ & $3 \%$ & 2.14 & $* *$ \\
\hline 1,702 & Not Priority Schools & $5 \%$ & & & \\
\hline 632 & VH Black Pop Schools & $11 \%$ & $7 \%$ & 5.17 & $* * *$ \\
\hline 1,458 & Not VH Black Pop Schools & $4 \%$ & & & \\
\hline 568 & VH Hispanic Pop Schools & $9 \%$ & $4 \%$ & 3.17 & $* * *$ \\
\hline 1,522 & Not VH Hispanic Pop Schools & $5 \%$ & & & \\
\hline 611 & VH Free Lunch Pop Schools & $10 \%$ & $6 \%$ & 4.16 & $* * *$ \\
\hline 1,479 & Not VH Free Lunch Pop Schools & $4 \%$ & & & \\
\hline 480 & VH White Pop Schools & $3 \%$ & $-4 \%$ & -4.46 & $* * *$ \\
\hline 1,610 & Not VH White Pop Schools & $7 \%$ & & & \\
\hline
\end{tabular}

Priority is an indicator assigned by the district to schools that either receive Title I funding or are failing to meet specified academic benchmarks. Schools with the $\mathrm{VH} \_$designation have student population of that characteristic in the $75^{\text {th }}$ percentile or higher. For Black students this is $16 \%$, for Hispanic it is $32 \%$, for White it is $57 \%$ and free lunch it is $45 \%$.

*** and ** indicate significance at the 0.01 and 0.05 levels, respectively. 
26 | Where are All the Black Teachers?

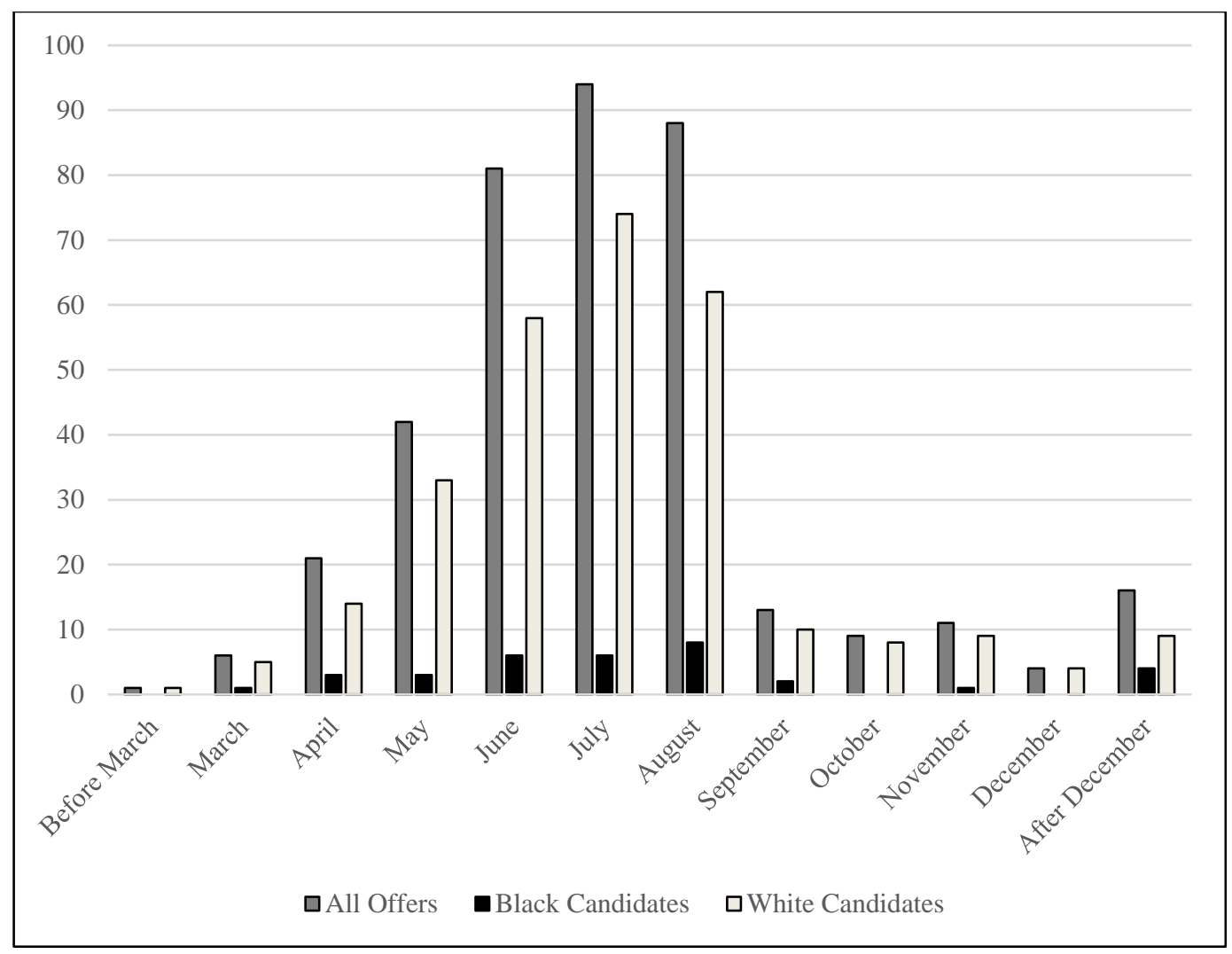

Figure 1. Panel A. Number of Offers at Priority Schools - White and Black Candidates

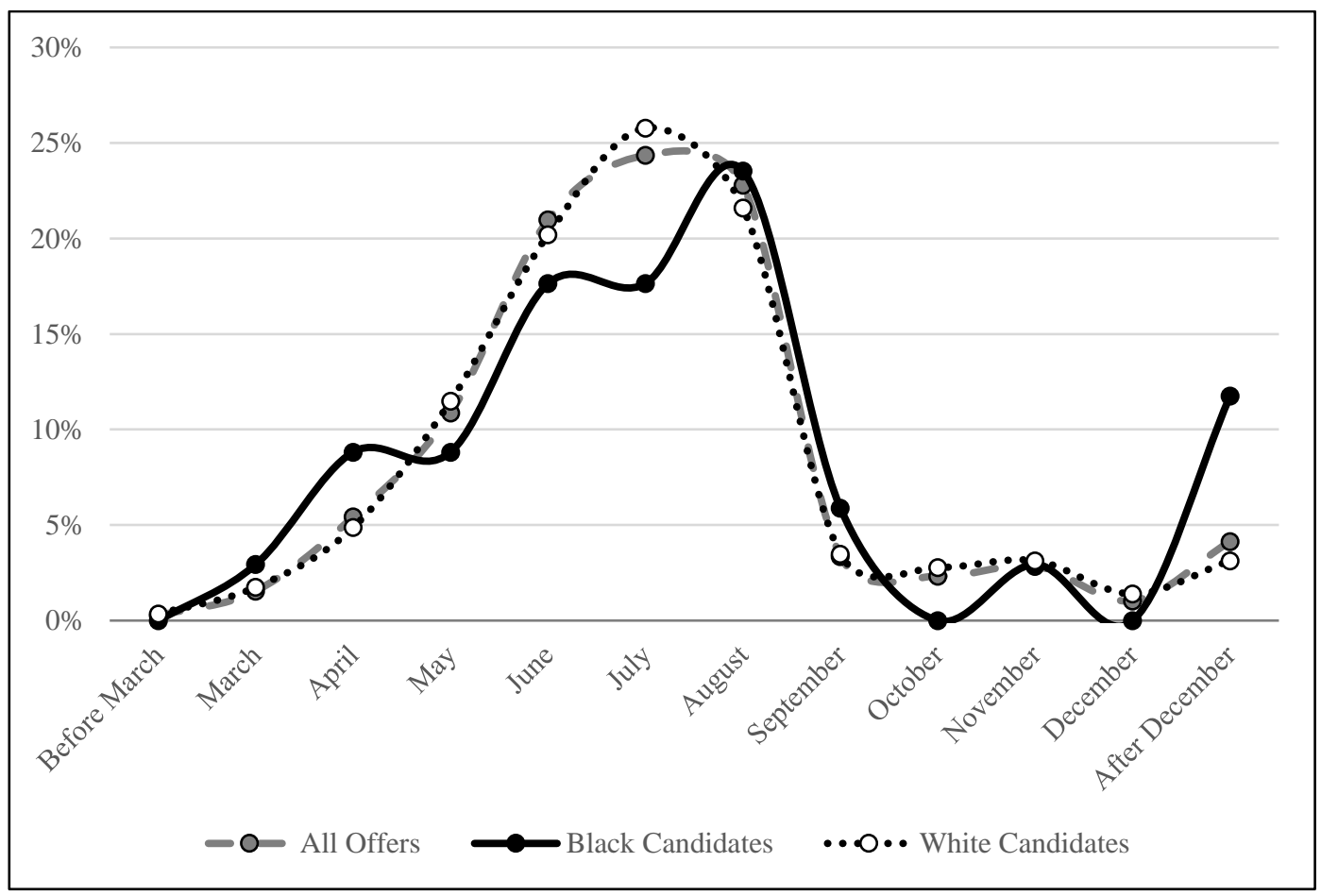

Figure 1. Panel B. Percent of Offers by Month - White and Black Candidates 
27 | Where are All the Black Teachers?

\section{References}

Achinstein, B., Ogawa, R. T., \& Speiglman, A. (2004). Are we creating separate and unequal tracks of teachers? The effects of state policy, local conditions, and teacher characteristics on new teacher socialization. American Educational Research Journal, 41(3), 557-603.

Albers, P. (2002). Praxis II and African American teacher candidates (or, is everything Black bad?). English Education, 34(2), 105-125.

Anderson, J. D. (1988). The education of Blacks in the South, 1860-1935. Chapel Hill: The University of North Carolina Press.

Angrist, J. D., \& Guryan, J. (2008). Does teacher testing raise teacher quality? Evidence from state certification requirements. Economics of Education Review, 27(5), 483-503. http://doi.org/10.1016/j.econedurev.2007.03.002

Author. (2016).

Authors. (2015).

Baumgartner, F. R., \& Jones, B. D. (2009). Agendas and instability in American politics. Chicago: University Of Chicago Press.

Bertrand, M., \& Mullainathan, S. (2004). Are Emily and Greg more employable than Lakisha and Jamal? A field experiment on labor market discrimination. American Economic Review, 94(4), 992-1013.

Bianco, M., Leech, N. L., \& Mitchell, K. (2011). Pathways to teaching: African American male teens explore teaching as a career. The Journal of Negro Education, 80(3), 368-383.

Boyd, D., Lankford, H., Loeb, S., Ronfeldt, M., \& Wyckoff, J. (2011). The role of teacher quality in retention and hiring: Using applications to transfer to uncover preferences of 


\section{8 | Where are All the Black Teachers?}

teachers and schools. Journal of Policy Analysis \& Management, 30(1), 88-110. http://doi.org/10.1002/pam.20545

Boyd, D., Lankford, H., Loeb, S., \& Wyckoff, J. (2005). The draw of home: How teachers' preferences for proximity disadvantage urban schools. Journal of Policy Analysis and Management, 24(1), 113-132. http://doi.org/10.3386/w9953

Boyd, D., Lankford, H., Loeb, S., \& Wyckoff, J. (2013). Analyzing the determinants of the matching of public school teachers to jobs: Disentangling the preferences of teachers and employers. Journal of Labor Economics, 31(1), 83-117. http://doi.org/10.1086/666725

Bridges, T. T. (2011). Towards a pedagogy of hip hop in urban teacher education. Journal of Negro Education, 80(3), 325-338.

Cain-Caston, M. (1999). A survey of opinions of North Carolina school administrators regarding factors considered most important in hiring teachers for their first teaching position. Journal of Instructional Psychology, 26(2), 69-73.

Census 2000 EEO Data Tool. (n.d.). Retrieved July 15, 2015, from http://www.census.gov/eeo2000/index.html

Colleague and Author. (2015).

D’Amico, T. F. (1987). The Ccnceit of labor market discrimination. The American Economic Review, 77(2), 310-315.

Dee, T. (2004). Teachers, race and student achievement in a randomized experiment. Review of Economics and Statistics, 86, 195-216.

Dillon, S. R., McCaughtry, N., \& Hummel, S. (2010). School districts' hiring practices for physical educators. Physical Educator, 67(4), 209-221. 
29 | Where are All the Black Teachers?

Dixson, A., \& Dingus, J. (2007). Tyranny of the majority: Re-enfranchisement of AfricanAmerican teacher educators teaching for democracy. International Journal of Qualitative Studies in Education, 20(6), 639-654.

Dobbie, W. (2011). Teacher characteristics and student achievement: Evidence from Teach for America. Retrieved from http://www.people.fas.harvard.edu/ dobbie/research.html/ Duncan, A. (2010, November 16). Remarks to national council for accreditation of teacher education. Retrieved September 30, 2015, from http://www.ed.gov/news/speeches/secretary-arne-duncans-remarks-national-councilaccreditation-teacher-education

Engel, M. (2012). The timing of teacher hires and teacher qualifications: Is there an association? Teachers College Record, 114(2), 1-29.

Engel, M., \& Cannata, M. (2015). Localism and teacher labor markets: How geography and decision making may contribute to inequality. Peabody Journal of Education, 90(1), 8492. http://doi.org/10.1080/0161956X.2015.988533

Fairclough, A. (2004). The costs of Brown: Black teachers and school integration. Journal of American History, 91(1), 43-55.

Foster, M. (1991). Constancy, connectedness, and constraints in the lives of African-American teachers. NWSA Journal, 3(2), 233-261.

Foster, M. (1997). Black teachers on teaching. New York: New Press.

Franklin, J. H. (1987). The desperate need for black teachers. Change, 19(3), 44-45.

Fultz, M. (2004). The displacement of Black educators post-Brown: An overview and analysis. History of Education Quarterly, 44(1), 11-45. 
30 | Where are All the Black Teachers?

Goldhaber, D., Grout, C., \& Huntington-Klein, N. (2014). Screen twice, cut once: Assessing the predictive validity of teacher selection tools. Seattle: Center for Education Data and Research, University of Washington.

Haberman, M. (1999). Increasing the number of high-quality African American teachers in urban schools. Journal of Instructional Psychology, 26(4), 208-212.

Hanushek, E. A., \& Rivkin, S. G. (2007). Pay, working conditions, and teacher quality. The Future of Children, 17(1), 69-96.

Harris, D. N., Rutledge, S. A., Ingle, W. K., \& Thompson, C. C. (2010). Mix and match: What principals really look for when hiring teachers. Education Finance and Policy, 5(2), 228246.

Heck, R. H. (2007). Examining the relationship between teacher quality as an organizational property of schools and student' achievement and growth rates. Educational Administration Quarterly, 43(4), 399-432. doi: 10.1177/0013161X07306452

Horng, E. (2009). Teacher tradeoffs: Disentangling teachers' preferences for working conditions and student demographics. American Educational Research Journal, 46(3), 690-717.

Hudson, M. J., \& Holmes, B. J. (1994). Missing teachers, impaired communities: The unanticipated consequences of Brown v. Board of Education on the African American teaching force at the precollegiate level. The Journal of Negro Education, 63(3), 388393. doi.org/10.2307/2967189

Ingersoll, R. M., \& May, H. (2011). Recruitment, retention and the minority teacher shortage. Philadelphia: CPRE.

Ingersoll, R. M., Merrill, L., \& Stuckey, D. (2014, April). Seven trends: The transformation of the teaching force. Philadelphia: CPRE. 


\section{1 | Where are All the Black Teachers?}

Ingle, K., Rutledge, S., \& Bishop, J. (2011). Context matters: Principals’ sensemaking of teacher hiring and on-the-job performance. Journal of Educational Administration, 49(5), 579610. http://doi.org/http://dx.doi.org.mutex.gmu.edu/10.1108/09578231111159557

Jacob, B. A. (2007). The challenges of staffing urban schools with effective teachers. The Future of Children, 17(1), 129-153.

Kingdon, J. (1984). Agendas, alternatives and public policies. Harper Collins Publishers.

Kirby, S. N., \& Hudson, L. (1993). Black teachers in Indiana: A potential shortage? Educational Evaluation and Policy Analysis, 15(2), 181-94.

Ladson-Billings, G. (2000). Fighting for our lives preparing teachers to teach African American students. Journal of Teacher Education, 51(3), 206-214. http://doi.org/10.1177/0022487100051003008

Lau, K. F., Dandy, E. B., \& Hoffman, L. (2007). The pathways program: A model for increasing the number of teachers of color. Teacher Education Quarterly, 34(4), 27-40.

Lilien, D. M. (1982). Sectoral shifts and cyclical unemployment. Journal of Political Economy, $90(4), 777-793$

Liu, E., \& Johnson, S. M. (2006). New teachers' experiences of hiring: Late, rushed, and information-poor. Educational Administration Quarterly, 42(3), 324-360. http://doi.org/10.1177/0013161X05282610

Madkins, T. C. (2011). The Black teacher shortage: A literature review of historical and contemporary trends. Journal of Negro Education, 80(3), 417-427.

Mertz, N. T. (2010). Teacher selection and school leader effects. Journal of School Leadership, 20(2), 184-207. 


\section{2 | Where are All the Black Teachers?}

Milner, H. R. (2012). Challenging negative perceptions of Black teachers. Educational Foundations, 26(1/2), 27-46.

Milner, H. R., \& Howard, T. C. (2004). Black teachers, Black students, Black communities, and Brown: Perspectives and insights from experts. Journal of Negro Education, 73(3), 285297. http://doi.org/10.2307/4129612

National Collaborative on Diversity in the Teaching Force. (2004). Assessment of Diversity in America's Teaching Force: A Call to Action. Retrieved from http://www.nea.org/assets/docs/HE/diversityreport.pdf

National Education Association. (n.d.). Teacher Diversity. Retrieved September 30, 2015, from http://www.nea.org//home/15200.htm

Pabon, A. J.-M., Anderson, N. S., \& Kharem, H. (2011). Minding the gap: Cultivating black male teachers in a time of crisis in urban schools. The Journal of Negro Education, 80(3), $358-367,435-437$.

Petchauer, E. (2012). Teacher licensure exams and Black teacher candidates: Toward new theory and promising practice. The Journal of Negro Education, 81(3), 252-267.

Reininger, M. (2012). Hometown disadvantage? It depends on where you're from: Teachers' location preferences and the implications for staffing schools. Educational Evaluation and Policy Analysis, 34(2), 127-145. http://doi.org/10.3102/0162373711420864

Rochefort, D. A., \& Cobb, R. W. (Eds.). (1994). The politics of problem definition: Shaping the policy agenda. Lawrence: University Press of Kansas.

Santelices, M. V., \& Wilson, M. (2010). Unfair treatment? The case of Freedle, the SAT, and the standardization approach to differential item functioning. Harvard Educational Review, 80(1), 106-133. 


\section{3 | Where are All the Black Teachers?}

Sleeter, C. E. (2001). Preparing teachers for culturally diverse schools: Research and the overwhelming presence of Whiteness. Journal of Teacher Education, 52(2), 94-106. http://doi.org/10.1177/0022487101052002002

Talbert-Johnson, C. (2001). The quest for equity: Maintaining African American teachers in special education. The Journal of Negro Education, 70(4), 286-296.

Tillman, L. C. (2004). (Un)intended consequences? The impact of the Brown v. Board of Education decision on the employment status of Black educators. Education and Urban Society, 36(3), 280-303. http://doi.org/10.1177/0013124504264360

Torres, J., Santos, J., Peck, N. L., \& Cortes, L. (2004). Minority teacher recruitment, development, and retention. Providence: Brown University.

Tyack, D., \& Cuban, L. (1997). Tinkering toward utopia: A century of public school reform. Cambridge: Harvard University Press.

Tyack, D., \& Tobin, W. (1994). The "grammar" of schooling: Why has it been so hard to change? American Educational Research Journal, 31(3), 453-479. http://doi.org/10.2307/1163222

United States Census Bureau. (2010). School enrollment. Retrieved September 29, 2015, from https://www.census.gov/hhes/school/data/cps/2010/tables.html

U.S. Department of Education. (2010). Characteristics of the 100 largest public elementary and secondary school districts in the United States: 2008-09. National Center for Education Statistics. Retrieved from https://nces.ed.gov/pubsearch/pubsinfo.asp?pubid=2011301

Villegas, A. M., \& Irvine, J. J. (2010). Diversifying the teaching force: An examination of major arguments. Urban Review, 42(3), 175-192. http://doi.org/10.1007/s11256-010-0150-1 
34 | Where are All the Black Teachers?

Walker, V. S. (2000). Valued segregated schools for African American children in the South, 1935-1969: A review of common themes and characteristics. Review of Educational Research, 70(3), 253-285. http://doi.org/10.3102/00346543070003253 